\title{
The Effect of Episodic Texts on Developing Saudi EFL Students' Vocabulary and Grammatical Competence
}

\author{
Issam Mostafa Ta'amneh \\ Tabuk University \\ KSA \\ Abeer Al-Ghazo \\ Ajloun National University \\ Jordan
}

\begin{abstract}
The present study aims at investigating the effect of Brown episodic model on developing Saudi EFL students' vocabulary and grammatical competence. To achieve the purpose of the study, the researchers prepared a vocabulary as well as a grammar test, which were used as pre-posttests. Moreover, the passages, which were chosen from the New Headway Plus, were changed into dialogues depending on episodic model. The sample of the study consisted 60 male EFL Saudi student who were studying Islamic studies at the university college of Taymaa in the academic year 2017/2018.The sample of the study was purposefully chosen to apply the study. The participants of the study were assigned into two groups; 30 students in the experimental and 30 students in the control groups. The study adopted the experimental design since one experimental group and one control group were selected purposefully. The data obtained from the students' responses in the vocabulary and grammar tests were analyzed using proper statistics analyses. The results of the study revealed that the scores of the students in the experimental group in the posttest were higher than the scores of the students in the control group. The results revealed that using episodic model had a positive effect in developing the Saudi EFL students' vocabulary and grammatical competence in the experimental group.
\end{abstract}

Keywords: Episodic model, vocabulary competence, grammar competence.

\section{Introduction}

For more many decades now, researches in English language teaching have identified the four skills- receptive skills- reading and listening, and productive skills- speaking and writing. It is said that EFL curricula and textbooks tend to focus on one or two of the four skills. Despite of treating the four skills in separate segments of a curriculum, there is a recent trend toward skill integration. All these skills are equally important, teachers should try to incorporate all of them into their lessons if they want to have a balanced approach and effective teaching and learning environment. We, as teachers or learners, may focus more on one particular skill but still bring others in to create an" integrated "skills lesson. The integration of the four speaking skills is necessary to master English as a foreign language. It is considered a new trend in teaching English.

The English language outcomes are organized into four skills of language use. English language teaching has a recent trend toward skill integration. Crystal (2003) stated that foreign language teaching has changed from concentrating on the language components such as; grammar, vocabulary, and pronunciation to a focus on the communicative proficiency and the integration of four skills: reading, writing, speaking, and listening. English language teaching process emphasizes the significance of communication in both the competence and the performance of the learners s' receptive as well as productive skills and in receptive as well as productive skills. Therefore, any English curriculum should be built adopting the communicative competence of the learners. The materials have approached these skills in an integrated way in terms of the tasks and activities for both learners and teachers. The following question could be raised concerning this issue. How can we maintain an integrated skills focus in our teaching? Brown (2000) stated the following models, which pull the direct attention of EFL students away from the separateness of the skills of languages and toward the meaningful purpose for which we use language. The first of the five models of integrated skills approach is Content-Based Instruction. It integrates the learning of some specific subject matter content with the learning of a second language. 
It is dictated more by the nature of the subject matter than by language forms and sequences. "Content-based teaching allows learners to acquire knowledge and skills that transcend all the bits and pieces of language that may occupy hours and days of analyzing in a traditional language classroom" (p. 235).Content based teaching presents challenges to language teachers allowing for the complete integration of language skill. If a teacher plans a lesson about a particular topic, his/ her task becomes how best to present that topic in an appropriate way to make easy and interesting. In adopting such strategy, students will get the information in an appropriate way. The second model of integrated skills approach is Theme-Based Instruction. Theme-Based Instruction is not the same as content-based. The differences between them are related to strong and weak version of content-based teaching. In the strong version, the primary content-based purpose of a course is to instruct students in a subject-matter area, and language is of secondary interest. A weak version forms an equal value on content and language objectives. Whereas theme based instruction provides an alternative to what would otherwise be traditional language classes by structuring a course around themes or topics. There are some possible theme-based activities :(Brown 2000. p.237)

1. Use environmental statistics and facts for classroom reading, writing, discussion, and debate

2. Carry out research and writing projects.

3. Have students create their own environmental awareness material.

4. Arrange field trips.

\section{Conduct simulation games.}

The third model of integrated skills approach is Experiential Learning. It emphasizes on two principles: 1) One learns best by doing an active experimentation and 2) inductive learning by discovery activates strategies that enable students to take charge of their own learning processes. Experiential learning techniques tend to be learner-centered by nature. It tries to put an emphasis on the psychomotor aspects of language learning by involving learners in physical actions in which language is subsumed and reinforced. The fourth of the five models of integrated skills approach is task-Based Language Teaching. In task-based instruction, the priority is on the functional purposes for which language must be used. Skehann (1998, p.95) defined a task as "an activity in which meaning is primary, there is some communication problem to solve and the assessment of it is in term of outcome". The last model of integrated skills approach is the Episode Hypothesis. The episode hypothesis contributes or relates to integrated-skills teaching. Here are some possible ways: Stories or episodes challenge the teacher and textbook writer to present interesting, natural language.2- Episodes can be presented in either written or spoken form. 3- Episodes can provide the stimulus for spoken or written questions that students respond to, in turn, by speaking or writing.4- Students can be encouraged to write their own episodes, or to complete an episode whose resolution or climax is not presented.5- Those written episodes might then be dramatized in the classroom by the students.

One of the keys to the success of the method lay in the presentation of language in an easily followed story line. Oller (1983b, p. 12) indicated that "text will be easier to reproduce, understand, and recall, to the extent that it is structured episodically." He also stated that "texts ,oral or written forms of discourse, which are more episodically organized can be stored and recalled more easily than less episodically organized material" (p , 44). This means that students learn language better and easier if they are given more logical and structured sentences through story line instead of disconnected phrases. According to the students, it is very important to learn vocabulary and texts in context and simple dialogue. This dialogue should have logical structure and logical conclusion. Oller stated that students can follow the story line step by step and can recall its structure more easily because logic helps them, and they do not have to rely only on memory. Brown (1994), pointed out that story line" motivated to continue reading and to become more involved in the content than in the language (p. 227)". As a result, learners will have a clear picture of what will happen and they will remember the words, expressions, events, facts and grammatical forms easily. Oller in his hypothesis advocates that the use of story line and dialogue facilitate vocabulary teaching. Brown (1994) also stated that the internalization of vocabularies come from comprehension and production of these vocabularies within the context of surrounding discourse. By using this way, learners can associate and recall the words with a certain context more better than learning them with corresponding meaning. Moreover, with the help of logical dialogue and logical structure, grammatical competence will be improved and practiced; students will be able to better recall the grammatical points, which embedded in a story later. 
Learners expand their vocabulary and grammatical competence when they are presented through episodically organized texts, because using dialogue process relies on both verbal and non-verbal communication that teachers can use visual aids such as flash cards, pictures, body language... etc. Many researchers assert on the idea that using dialogue and storytelling expand students' range of vocabularies and provide an encouraging framework for vocabulary learning. (Cooper, Collins, \& Saxby, 1992; Elley, 1989).

In term of grammatical competence, episodic text through dialogue had served as a stepping-stone to the learning of grammatical and syntactic features. Using dialogue may help students make immediate application of grammatical concepts. Brown (2000) stated that grammar is contextualized in meaningful language use and communicative context. Consequently, grammar and vocabulary concepts should be given a lot of attention and concern to help the learners to improve their language competence inside the classroom and outside it. Students' lack of opportunities to communicate in English may be one of the obstacles that stand against the students' progress in learning English skills and grammatical features. Therefore, teachers are the key agents and figures that determine the students' success to learn English as a foreign language. Teachers can facilitate learning the vocabularies and grammar features when they use many meaningful and purposefully activities and strategies.

\section{Literature Review}

In his instructional approach of contextualized storytelling, Cary (1998) tried to improve ESL learners' English acquisition in the U.S. The researcher used contextualized storytelling which is a multi-sensory approach; it relies upon both verbal and non-verbal communication in the story-telling process. This process uses visual aids, heavy props, proper prosodic delivery, rich body language and concrete referents for vocabulary. This (story-telling process) is different from traditional story where a folk art highlights the verbal performance of storytellers. Cary revealed that there are positive effects of this approach on improving speaking comprehension and retention of oral narratives by the ESL learners.

Dabbagh (2017) tried to evaluate the effect of dialogue journal writing on writing performance as well as its different sub-components, namely content, organization, vocabulary, language use, and mechanics. He selected 84 EFL intermediate learners as participants in this study. They were selected according to their performance on Oxford Quick Placement Test (2004) and divided randomly into experimental and control groups. To answer the questions of the study, the researchers used an achievement writing comprehension test as a pre-test and a posttest to the experimental and the control groups with some modification related to the methodology each group was taught accordingly. The learners in the control group took part in descriptive writing pre and post-tests only, while the learners in the experimental group were asked to write 3 journals a week for about 6 months in the period between the pre- and post-tests. The results revealed that there are significant difference between the experimental and control group regarding the overall writing performance.

Foroutan, et al Noordin, and Hamzah (2013a) investigated the effect of email dialogue journal writing in enhancing writing performance. The participants were divided into experimental and control group. While the control group was asked to write a paper and pencil version of writing, the experimental one was asked to write an email dialogue journal writing. The results revealed that the learners in the experimental performed better not only in overall writing but also the language use aspect than those in the control one. Ahmadian, et al (2014) investigated the effect of collaborative dialogue on vocabulary acquisition and retention of EFL learners. For that purpose, 64Iranian lower intermediate EFL learners were selected as the participants of the study. Oxford Placement Test. had confirmed them that they were homogeneous. They were divided into two collaborative and individual groups. The researchers developed six tasks then implemented at three stages of pre-task, during-task, and post-task. Vocabulary test in three occasions is constructed to compare the groups' performance and assess the students` comprehension. To achieve the purpose of the study, the scores of two groups were compared at the end of instruction period. The results revealed that the collaborative technique had significantly immediate and delayed effects on vocabulary acquisition and retention of the collaborative group. Based on the notion of Swains' collaborative dialogue (2005), Barbadian and Moezzy (2011) investigated the vocabulary acquisition. The participants of this research were 60 intermediate EFL learners. They were divided into control and experimental group. The participants taught a list of 30 words but in two different ways. While the participants in the experimental group were engaged in three tasks, the control one was given defining and memorizing the vocabularies tasks. For the purpose of the study, the scores of pre and post tests of control and experimental group were compared at the end of instruction period. 
The results revealed that the post-test scores of the experimental group were significantly higher than those of the control group. This means that the participants in the experimental group showed a significant improvement in vocabulary acquisition.

Rokni \& Seifi (2013) investigated the effect of dialog journal writing on learners' development grammar. The sample of the study consisted of 68 students who were randomly chosen from Golestan University, Iran. The participants were assigned into two groups, the experimental group and the control group. The learners in the experimental group were instructed to write a journal every session, overall twelve journal entries during the treatment, while the control group did not receive any treatment. To answer the questions of the study, a test is used as a pre-test and a post-test to both; the experimental and the control group with some modification related to the way of treatment each group is taught accordingly. The findings revealed that journal writing had a significant positive effect on students' grammar knowledge and enhanced their confidence in writing.

Abdolmanafi-Rokni \& Seifi (2013) examined the effect of dialog journal writing on Iranian EFL learners' vocabulary knowledge. They chose 46 EFL participants to participate in that study. They were divided into control group and experimental one. They had been confirmed that they were homogeneous group by a proficiency test and then pretested by a vocabulary test. To answer the questions of the study, the participants in the experimental group were asked to write dialog journals twice a week for twenty sessions. They wrote one at home and the other in the classroom. While the learners in other group receive a placebo. The results revealed that dialog journal writing had a significant effect on EFL learners' vocabulary knowledge, improved writing quality and fluency, reduced anxiety of writing, organized class activities and built community in the classroom. Adam, M (2013) tried to enhance EFL Learners' competence through short stories. In order to answer the questions of the study, the researcher used a questionnaire to collect the data and Achievement Test Reports. Eighty undergraduate students and with the assistance of ten English language teachers in four colleges participated in this study. The participants in the experimental group were taught the syllabus components for the semester directly or otherwise using the short story. The control group were taught using the prevalent pedagogy. The results revealed that the contextualized storytelling was found to be an effective intervention in reading comprehension for both proficient and less proficient students; and the less proficient students seemed to profit more from this approach.

Aziz \& Magdalena (2016) investigated the opinions of scholars toward using dialogue journals to improve their writing skills of young learners. This study was conducted in the form of library research. To meet the aims of the study, the researchers analyzed various written resources such as relevant textbooks, online documents, journal articles, etc. The results show that the use of dialogue journals has improved the writing skills of young learners especially in terms of vocabulary and grammar.

\section{Purpose and Questions of the Study}

The main purpose of this study was to examine the effect of episodic texts on developing Saudi EFL students' vocabulary and grammatical competence.

To be more specific, the study aimed to answer the following main questions:

1-Is there any significant difference in the Saudi EFL students 'vocabulary competence between the control group and the experimental group due to Brown's episodic model?

2-Is there any significant difference in the Saudi EFL students' grammar competence between the control group and the experimental group due to Brown's episodic model?

\section{Statement of the Problem}

Mastering grammar as well as vocabulary is considered nowadays one of the basic requirements for EFL learners to learn English. The majority of the Arab students move from one academic stage into another with a shortage in the vocabulary store, which leads to a lot of learning difficulties. This fact stands against achieving any academic progress in their present as well as future academic progress. This fact reflects the students' bad and poor results when they are set to do some reading comprehension tests. Moreover, the lack of the students' vocabulary bank creates a lot of difficulties when they are asked to deal with some reading comprehensions. Vocabulary should be given a lot of attention because if the learner learns the structure and not the content, then he/she is expected to produce a meaningless utterance (Johnson 1977, p.1). Another problem is the fact that many students face a lot of grammar difficulties. The researchers believe that the shortage of learners' grammar knowledge results in bad unacceptable conversations especially when they are set for making interviews to get a job. 
It is said that the recognition of vocabulary as well as the knowledge of each part of speech are necessary objectives for language learning (Celce-Murcia and Rosensweig 1979).

According to Al Regeb (2009) who confirmed that the school students face many difficulties when they start reading different texts. This could be explained that the lack of students' store of vocabulary is the main reason behind that.Celce-Murcia and Rosenstein (1979) stated that vocabulary as well as grammar are necessary for students' development for both native and non-native speakers. It is expected that students who have a good number of vocabulary and a good knowledge of grammar are better learning achievers than those who do not. The researchers believe that this situation is close to the nature of Saudi students in the schools and colleges. The problem becomes big when the teachers as well as students do not care about the importance of vocabulary and grammar in the learning process as vocabulary is considered crucial in the process of comprehending texts. Wilkins (1972, p.111) stated, "Without grammar very little can be conveyed, without vocabulary nothing can be conveyed". It means that it will be useless if the learners have good grammar but they do not know many vocabularies This situation should encourage teachers to use some effective models that help in improving and developing students' vocabulary and grammar abilities. It is expected that using Brown's episodic model may help in improving students' grammar and vocabulary in the basic stage as it helps in promoting the integration of English language skills.

\section{Significance and Limitations of the Study}

Since vocabulary and grammar are considered vital skills for learning to read, speak and write, the results of this study could be very helpful to the learners and EFL teachers as they give a clear picture on the importance of using episodic texts on developing the students' vocabulary and grammatical competence. The findings also may have a positive impact on improving the quality of linguistic proficiency through implementing the explicit instruction of using episodic model, because using episodic model make students active in the reading and writing process. In addition, the recommendations of this study open venues for further research on the importance of such hypothesis in developing the Saudi students' English skills to enhance and improve teaching pedagogy and learning conditions in Saudi Arabia.

\section{The generalization of the results of this study is limited due to the following factors:}

1-The study is limited in number and gender. Only 30 EFL Saudi male students participated in the study from each section. Each section consisted of about 55 students. The sample was chosen purposefully to achieve the purpose of the study.

2-The study is limited in the number of the reading comprehension passages that were chosen to achieve the goal of the study. Only three reading passages were chosen out of 10 reading passages. These three passages were chosen purposefully because the researchers felt that they were able to achieve the aims of the study.

\section{Methodology and Scope of the Study}

\subsection{Design of the Study}

The present study adopted the experimental design since one experimental group and one control group were selected purposefully. This section also presents the methodology of the study. It includes the participants of the study, research instruments, procedures, statistical analysis, data collection and data analysis procedures.

\subsection{The Participants of the Study}

The participants in this study consist of two sections of students who are studying New Headway Plus in their first semester at the new academic year 2017/2018 at the University college of Taymaa. The total number of the participants in this study was 30 EFL learners.30 learners in the control group and the same number in the experimental group. All of them are male EFL learners whose specialization in the college is Islamic Studies. Their age ranged from 18 to 19 years old who have just completed their secondary certificate and enjoyed the university. The participant is scheduled to attend the course five times a week. Each meeting lasts for an hour for each group as they take the course in two different times. The participants are randomly assigned into a control group as well as an experimental group. The control group was taught in a traditional way and as it was described in the student's book whereas the experimental group was taught according to Brown's model (2000) which is called the episodic model that is based mainly on teaching deepening on different teaching techniques such as using the dialogue, stories, and episode completion. 


\subsection{Research Instrument}

In order to achieve the study objectives, the researchers used the following:

1-An achievement vocabulary test (Appendix A) which is to be used as a pre-test to both; the experimental and the control group. The vocabulary test consists of space completion questions. 27 words were chosen carefully from the three passages that were chosen to be the subjects of the study. 2-An achievement grammar test (Appendix B) which is to be used as a post-test to both; the experimental and the control group with some modification related to the ways each group is taught accordingly. The grammar test consists of different types of questions such as a multiple-choice question, word correction and written response questions.25 grammar questions were used in the grammar test that was provided to the participants in both groups; the experimental and the control groups. The total number of the items that were used in the vocabulary and the grammar test was 52 items.

\subsection{Procedures}

Three texts, from New Headway Plus, which was published by John and Liz Soars, "The Secret Millionaire", "What's on your plate?" and "Past, Present and Future "were chosen to apply the study. These three texts were chosen as the researchers felt that they were the appropriate texts that could be changed them into dialogues and suit the purpose of the study, which was based on using Brown's episodic model in the teaching process for the experimental group only. The researchers kept the same characters and similar settings. Achievement vocabulary and grammar comprehension tests are used as pre-tests to both; the experimental and the control group. To guarantee the homogeneity of the groups, a multiple-choice and written response questions test of 25 questions are constructed to assess the students` comprehension of vocabulary and grammar. These questions cover a range of objectives in the area of reading comprehension including; identifying the main idea, analyzing characters, summarizing the text, comprehend the details and making inferences. It could be seen the homogeneity between the two groups according to the average scores of them.

Depending on the participants' answers to pretest items; the researchers extract a list of those vocabularies and words that are unfamiliar to them. They also noticed how grammatical competence they have. All of the three reading texts were taught to both control and experimental groups. In the next step, and in order to instruct learners effectively to employ episodic texts, reading texts are changed into dialogue forms and they well illustrated with pictures that explain the words and grammatical features. While the experimental group taught the texts through dialogue, the same texts were taught to the control one through the traditional methods, which were based on using mother tongue language or translation. This study has been conducted for a period of one month (4weeks) in an environment where learners received English class for two hours each week. After that and in order to show the effect of these two different methods of instructions on the learners' vocabulary and grammatical comprehension development, the test scores of the two groups were compared as posttest obtained after the treatment. Then the data were analyzed using SPSS software. The procedures, that the two researchers adopted to form both the vocabulary and the grammar tests, were the following:

\subsection{Variables of the Study}

The study includes the following variables:

1. The independent variable was the teaching strategy (the Brown's episodic model, and the conventional way of teaching).

2.The dependent variables were the participants' mean scores in the vocabulary and the grammar tests.

\subsection{Data collection}

To collect the data in the study, quantitative techniques were used to analyze the data obtained from the vocabulary and the grammar tests.

\section{Results and Discussion}

To examine the effect of episodic texts on developing Saudi EFL students' vocabulary and grammatical competence, the researchers tried to see if there is any significant difference in the Saudi EFL students' vocabulary and grammar competence between the control group and the experimental group due to the episodic model. The homogeneity of the control and experimental group was examined by analyzing their scores in the pre-test. 
The researchers used the independent samples T-Test to analyze the possible variances in grammar and vocabulary comprehension between the two groups. Table 1 presents the means and standard deviations obtained by the experimental group and the control group on vocabulary pre-test.

Table 1:Table (1) Means and standard Deviations for Students' Vocabulary Scores on the Pre test

\begin{tabular}{|c|c|c|c|c|c|c|c|c|c|}
\hline \multirow[t]{2}{*}{ Sig } & \multicolumn{2}{|r|}{ Mean } & \multicolumn{2}{|r|}{ St } & \multirow{2}{*}{ df } & \multirow[t]{2}{*}{$\mathrm{T}$} & \multicolumn{2}{|c|}{$\begin{array}{l}\text { Levene's Test for } \\
\text { Equality of Variance }\end{array}$} & \\
\hline & $\begin{array}{r}\text { Control } \\
\text { group }\end{array}$ & $\begin{array}{c}\text { Experiment-al } \\
\text { group }\end{array}$ & $\begin{array}{l}\text { Control } \\
\text { group }\end{array}$ & $\begin{array}{c}\begin{array}{c}\text { Experiment-al } \\
\text { group }\end{array} \\
\text {. }\end{array}$ & & & Sig & $\mathrm{F}$ & \\
\hline $\begin{array}{l}0.810 \\
0.810\end{array}$ & 2.37 & 2.47 & 1.586 & 1.613 & $\begin{array}{r}58 \\
57.98\end{array}$ & $\begin{array}{r}0.242 \\
0.242\end{array}$ & 0.674 & 0.178 & $\begin{array}{r}\text { Equal } \\
\text { Variances } \\
\text { assumed } \\
\text { Equal } \\
\text { Variances not } \\
\text { assumed }\end{array}$ \\
\hline
\end{tabular}

Statistically significant at the Level $(\alpha=0.05)$

Table one shows that the control and the experimental groups were homogenous in terms of vocabulary knowledge test at the beginning of treatment and instructional tasks since the results revealed that there are not any significant differences $(\mathrm{t}=-.242 ; \mathrm{p}>.05)$ between the mean scores of the students in the two groups. Subsequently, the experimental group taught the texts through dialogue, while the same texts were taught to the control one through the traditional methods, which based on using mother tongue language or translation. Table 2 below presents the means and the standard deviations obtained by the experimental group and the control group on grammar pre-test.

Table 2: The Means and Standard Deviations Obtained by the Experimental Group and the Control Group on Grammar Pre-test.

\begin{tabular}{|c|c|c|c|c|c|c|c|c|c|}
\hline \multirow[t]{2}{*}{ Sig } & \multicolumn{2}{|c|}{ Mean } & \multicolumn{2}{|r|}{ ST.D } & \multirow[t]{2}{*}{$\mathrm{df}$} & \multirow[t]{2}{*}{$\mathrm{T}$} & \multicolumn{2}{|c|}{$\begin{array}{lrr}\text { Levene's } & \text { Test for } \\
\text { Equality } & \text { of } \\
& \text { Variance }\end{array}$} & \\
\hline & $\begin{array}{r}\text { Control } \\
\text { group }\end{array}$ & $\begin{array}{c}\text { Experimental } \\
\text { group }\end{array}$ & $\begin{array}{r}\text { Control } \\
\text { group }\end{array}$ & $\begin{array}{c}\text { Experimental } \\
\text { group }\end{array}$ & & & Sig & $\mathrm{f}$ & \\
\hline $\begin{array}{l}0.891 \\
0.891\end{array}$ & 3.23 & 3.17 & 2.254 & 1.392 & $\begin{array}{r}58 \\
48.3\end{array}$ & $\begin{array}{l}0.138 \\
0.138\end{array}$ & 0.087 & 3.028 & $\begin{array}{r}\text { Equal } \\
\text { Variances } \\
\text { assumed } \\
\text { Equal } \\
\text { Variances not } \\
\text { assumed }\end{array}$ \\
\hline
\end{tabular}

Statistically significant at the level $(\alpha=0.05)$

According to the analysis of the pre-test scores, Table (2) shows that there are not any significant differences $(t=-0.138 ; p>.05)$ between the mean scores of the students in the two groups .This means that the two groups were homogeneous in terms of grammatical competence level before the beginning of the experiment and the treatment. The grammar constructions in the dialogues handed out to the experimental group, while the other group did not receive any treatment or take part in this phase of experiment. In order to examine the effect of episodic texts on developing Saudi EFL students' vocabulary and grammatical competence, both groups were administered vocabulary and grammar post-test at the end of the treatment process (see Table 3).

Table (3): Means and Standard Deviations for Students' Scores on the Vocabulary Post- test

\begin{tabular}{|r|r|r|r|r|}
\hline \multirow{2}{*}{ Sig } & \multicolumn{2}{|r|}{ Mean } & $\mathrm{df}$ & $\mathrm{T}$ \\
\cline { 2 - 3 } & \multicolumn{1}{|c|}{ control } & Experimental & & \\
\hline .001 & 3.50 & 6.83 & 58 & $3.620-$ \\
\hline
\end{tabular}

Table 3 shows that there is an observed difference between the two means of the students' achievement in the vocabulary post-test due to the received treatment. After the treatment, one can clearly notice that the mean score obtained by experimental group (6.83) is higher than the mean score obtained by control group (3.50). 
The table shows that there were differences between the mean scores of the students in both groups; experimental and control in the vocabulary post-test. To investigate the significance of the observed difference, ANOVA was used for the students' achievement in the posttest due to the teaching strategy. The results are presented in Table 4.

Table (4): Results of a One - Way Variance Analysis of the Scores of Students in the Study Sample on Post Vocabulary Test According to the Teaching Method

\begin{tabular}{|r|r|r|r|r|r|}
\hline Source of Variation & SS & d.f & MS & f & Sig \\
\hline Between Groups & 166.667 & 1 & 166.667 & 13.104 & .001 \\
\hline Within Groups & 737.667 & 58 & 12.718 & & \\
\hline Total & 904.333 & 59 & & & \\
\hline
\end{tabular}

The table above shows that there are statistically significant differences ( $f: 13.104$ ) at $\alpha=0.05$ between the adjusted two means for the post students' achievement in the test due to the teaching strategy as indicated in Table 3 , in favor of the students in the experimental group who were taught using episodic texts compared with the students of the control group who were taught according to the traditional way of teaching.

Table (5): Means and Standard Deviations for Students' Scores in the Grammar Post- test

\begin{tabular}{|c|c|c|c|c|}
\hline \multirow[t]{2}{*}{ Sig } & & Mean & \multirow[t]{2}{*}{$\mathrm{df}$} & \multirow[t]{2}{*}{$\mathrm{T}$} \\
\hline & Control & Experimental & & \\
\hline .000 & 5.80 & 8.40 & 58 & $4.685-$ \\
\hline
\end{tabular}

Given the information above, and after the experiment and the treatment, one can clearly see that the mean score obtained by experimental group (8.40) is higher than the mean score obtained by control group (5.80). The table shows that there were differences between the mean scores of the students in both groups; control and experimental in the post-test. In other words, the experimental group outperformed the control group in the grammar post-test. Therefore, it can be claimed that the performance, and after the explicit instruction on using episodic texts, seemed to have contributed to improve the Saudi EFL students' grammatical competence. To investigate the significance of the observed difference, ANOVA was used for the students' achievement in the posttest due to the teaching strategy. The results are presented in Table 6.

Table (6): Results of a One - Way Variance Analysis of the Scores of Students in the Study Sample on post grammar Test According to the Teaching Method ANOVA Table

\begin{tabular}{|l|l|l|l|l|l|}
\hline Source of Variation & SS & d.f & MS & f & Sig \\
\hline Between Groups & 101.400 & 1 & 101.400 & 21.945 & .000 \\
\hline Within Groups & 268.000 & 58 & 4.621 & & \\
\hline Total & 369.400 & 59 & & & \\
\hline
\end{tabular}

The table shows that there are statistically significant differences at $\alpha=0.05$ (f: 21.945 ) between the adjusted two means for the post students' achievement in the post grammar test due to the teaching strategy as indicated in table 6 , in favor of the students in the experimental group who were taught using episodic texts compared with the students of the control group who were taught according to the traditional way of teaching. The progress that appeared among the scores of students' in the experimental group compared with the scores of the students in the control group was due to applying the episodic text in the study by changing the ordinary texts into dialogue ones. This fact is supported by Oller (1983b);Elley (1989); Cary (1998);Cooper, Collins, \&Saxby (1992); and Brown (1994) who all agreed that changing the texts into dialogues could improve the students' performance in different language skills such as reading, writing, and speaking. The results of this study goes in complete harmony with other studies that were examined by other researchers such as Baradaran and Moezzy (2011), Rokni and Seifi (2013), and Ahmadian, et al (2014) who all agreed that using the episodic texts in teaching vocabulary had a great effect in developing the students' vocabulary comprehension. The present study may differ from other studies that were conducted by other researchers as they measured the effect of the episodic text model in developing the students' writing skill (Foroutan, et al Noordin, and Hamzah (2013a), Aziz and Magdalena (2016) Dabbagh (2017). All these studies pointed out that using the episodic texts helped the researchers in developing their participants' writing skill. On the other hand, the study, which was conducted, by Marajan, and Adam (2013) tried to investigate the effect of the episodic texts on developing the learners' reading comprehension while the present study investigated the effect of the episodic texts in developing the Saudi EFL learners' grammar and vocabulary competence. 
The results of this study as stated above confirmed the other researchers' studies that pointed out that using and applying the episodic texts to develop the EFL learners' linguistic competences have a positive effect in achieving that.

\section{Conclusion}

The main purpose of the present study was to investigate the effect of episodic texts on developing Saudi EFL students' vocabulary and grammatical competence. The results of the study showed that using the episodic model in teaching vocabulary and grammar had a great effect on developing their vocabulary and grammatical competence, as the results of the vocabulary and grammar post-tests for the students showed that the students in the experimental group, who were taught according to the episodic texts, achieved better scores compared with the students' results in the control group, who were taught according to the traditional way of teaching. The results of the study pointed out that the achievement of the students in the experimental group was better than the results of the students in the control group due to the fact that involving students in dialoguers while teaching will certainly lead to a kind of progress in their vocabulary and grammatical competence instead of following the traditional way of teaching. Based on the results of the present study, the researchers recommended adopting the episodic model in teaching other English language skills such as writing and listening. Moreover, the researchers advised other researchers to investigate other models, which were suggested by Brown and Oller such as contentbased instruction model, theme-based instruction model, and experiential learning model to investigate their effects on improving and developing the students' competence in other language skills and for other educational levels. Finally, the researchers looked at adopting these models in teaching English, as a foreign language, as excellent useful methods in developing the EFL learners' competence.

\section{References}

Abdolmanafi Rokni, S.J. and Seifi, A. (2013), The effect of dialog journal writing on EFL learners' grammar knowledge. The Journal of Language and Linguistic Studies, 9(2), 57-67.

Abdolmanafi-Rokni, S., and Seifi Zoghi, A. (2013). Does Dialog Journal Writing Have any Effect on EFL Learners' Vocabulary Knowledge? Int. J. Appl. Ling. Stud., 2(2): 38-42

Adam,M. (2013). Enhancing EFL Learners' Competence through Short Stories: A Study in Four Colleges. Advances in Language and Literary Studies, 4 (1), 154-158.

Ahmadian, et al.(2014) .The effectof collaborative dialogue on vocabulary acquisition and retention of EFL learners.International Journal of Applied Linguistics \& English Literature. 3(4), 38-45.

Dabbagh, A. (2017).The Effect of Dialogue Journal Writing on EFL Learners' Descriptive Writing Performance: A Quantitative Study. International Journal of Applied Linguistics \&English Literature. 6(3).P.71.

$\mathrm{Al}$ Regeb, K. (2009). .The effect of semantic mapping and group discussion on Jordanian secondary stage students' reading comprehension and verbal communication in English. Unpublished PhD Dissertation. Amman Arab University. Amman. Jordan

Aziz,and Magdalena, (2016) .Using a dialogue journal to develop writing skills. English Education Journal(EEJ), 7(4), 416-432

Baradaran, A., \& Moezzy, M. (2011). A study of the role of collaborative negotiation in the acquisition of lexical meaning. Australian Journal of Basic and Applied Sciences, 5(21), 2252-2259.

Brwon, H.D. (2000). Teaching by principles: An interactive approach to language pedagogy. On Francisco: State University.

Brown, D. (1994). Principles of language learning and teaching. Englewood Cliffs, NJ: Prentice Hall.

Cary, S. (1998). The effectiveness of a contextualized storytelling approach for second language acquisition. (UMI Microform 9828452)

Celce-Murcia, M. \& Rosensweig, F. (1979). Teaching vocabulary in an ESL program. In M. Celce-murcia \& L. McIntosh (Eds.), Teaching English as a second or foreign language. Rowley, Massachusetts: Newbury House publishers Inc.

Cooper, P. J., Collins, R., \& Saxby, M. (1992). The power of story. Melbourne: MacMillan.

Crystal, D. (2003). English as a Global Language (2nd Edition). Cambridge: University Press

Elley, W. (1989). Vocabulary acquisition from listening to stories. Reading Research Quarterly, 24, 174-187. 
Foroutan, M., Noordin, N., \& Gani bin Hamzah, M.S. (2013a). Use of e-mail dialogue journal in enhancing writing performance. Asian Social Science, 9(7), 208-217.

Oller, W.(1983 b). Story writing principles and ESL teaching. TESOL Quarterly 17,39-53.

Skehan, P. (1998) A cognitive approach to language learning. Oxford, Oxford UP.

Swain, M. (2005). The output hypothesis: Theory and research. In E. Hinkel (Ed.), Handbook of research in second language teaching and learning (pp. 471-484). Mahwah, NJ: Lawrence Erlbaum.

Wilkins, D.A. (1972).Linguistics in language teaching. London: Edward Arnold Ltd.

\section{Appendix A}

Name:

Student's No.(...........)

Passage (1) Vocabulary Test

(The Secret Millionaire)

Q.1-Choose one of the following words to complete the sentences below

worth - teenage - private - couple- secret- hostel-flat - homeless - missing

1-John is a rich football player. He has a ....................plane.

2-Ali told his close friend a .... . He asked him not to tell anybody about it.

3 -His car is now $£ 20,000$

4-My uncle has two ............sons. They are studying at The University College of Taymaa.

5-My friend Khaled lives in Amman. He runs a.............for poor boys.

6-In Africa, it is usually to see thousands of ...........children especially in big cities.

7-Fatima travelled to Paris for studying French. She is her family a lot.

8- Ali bought a beautiful and expensive... in Amman last week.

9-Ali and Fatima are a happy ..........who have been marring for 15 years.

Passage (2) $\quad$ Vocabulary Test. Pres
Q.2- Choose one of the following words to complete the sentences below:

(Psychology - economics - journalist - chef - excited - worried - architect - grew up - developing - trip nervous-campus)

10-Kevin was born in Paris, but he. in London where his parents are working.

11-Ahmad lives in the university.... with two of his friends.

12-The ..............countries in Africa need help and support from UN.

$13-\ldots . . . . . . .$. .refers to the study of human behavior, thought and mind.

14-John is a............. at a famous British newspaper.

15-The social science that is concerned with production and consumption is called................

16-I have an English exam tomorrow. I am completely ............about the exam.

17-Ahmad was ..............when he passed the driving test.

18-The driver was ...............when he got a driving ticket from a near police station because of driving fast.

19-Tareq works as a ................at one of famous restaurants in Cairo.

20 -We went in a sea ........... to the seaside.

$21-$ The ...........is the person who designs houses and buildings.

Passage (3) Vocabulary Test. (What's on your plate?)

\section{Q.3 - Choose one of the following words to complete the sentences below:}

( toast-cereal - snack - waiter-bike - meal)

22-Before I go to school, I used to take a

with me like a cheese sandwich.

23-John is a in the Golden Restaurant for sea food.

24-For breakfast, Sara prefers with milk.

25-The lunch is my main

26-I want two slices of

27- I ride my for my bread. to school every day as a kind of sport. 


\section{Appendix B}

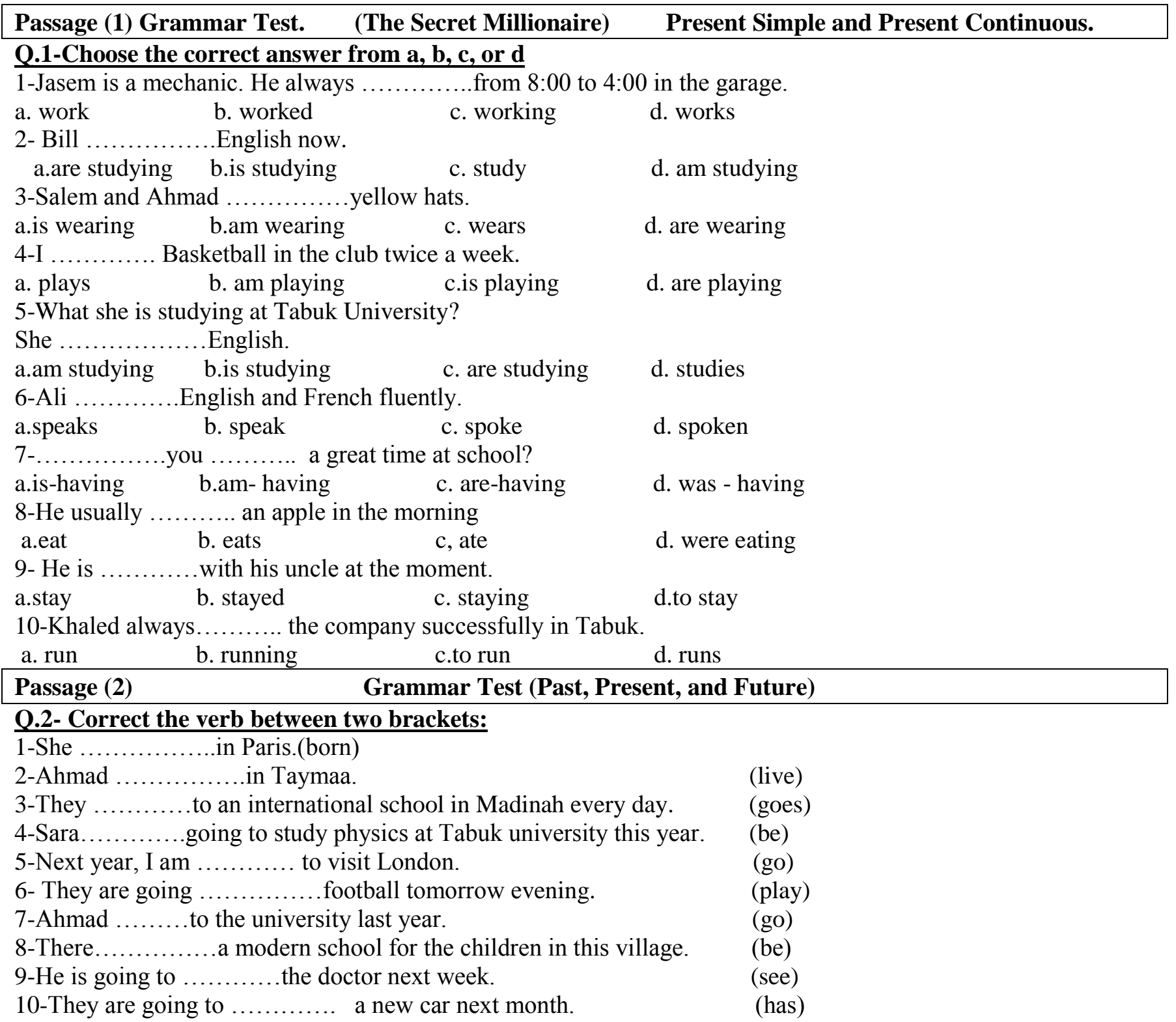

Passage (3) Grammar Test (What's on your plate?)

Q.3- Complete the following questions about yourself.

1 -Where.........................................?

I live in Taymaa.

2-How many ..................................?

I have 3 brothers.

3 -What ...................................?

I ate pizza.

4-What ....................................?

I am studying English.

5-Whom ?

I met my brother yesterday.

THE END 


\section{Appendix C}

The PowerPoint Presentation

Reading Passages

Reading Passage 1

\section{Passabe 1-_ "The Secret Millionaire"}

Worth: worth ${ }^{1}$ /wrsie/ prep.

good or important enough to justify: That place is definitely worth visiting.

having a value of:That vase is worth 20 dollars.

having property to the value of:They are worth millions.

n. Luncountablel

excellence, as of character;
merit:a man of worth.

usefulness or importance, as to the world, to a person, or for a purpose-Your worth to the team is unquestionable.

value, as in money.

a quantity of something of a specified value:The storekeeper gave him 50 cents' worth of candy.

property or possessions;

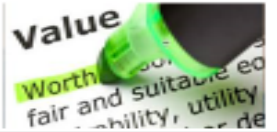


Teenage: teen•ag•er (tēn'ấ'jer), $\mathbf{n}$.

1. a person in his or her teens.

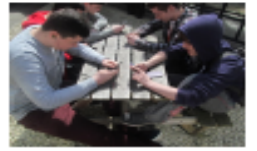

teen•age /'tin erd3/ also 'teen aged, adj.

1. of, relating to, or characteristic of people in their teens.

teen・ag•er, n. [countable]

Name:

Passage (3) Part 1

(What's on your plate?)

Ali: Hello, good morning.

Masumi: Hello. Good morning. Niece to meet you.

Ali: What is your name?

Masumi: My name is Masumi. What is your name?

Ali: My name is Ali

Masumi: Where are you from?

Ali: I am from Kuwait. And you?

Masumi: I am from Japan

Ali: Where do you live Masumi?

Masumi: I live in Tokyo.

Ali: Great. Tokyo is the capital of Japan. It is an industrial city.

Masumi: That's right. Tokyo is a very clean and developed city. What about you? Where do you live?

Ali: I live in Riyadh. It is the capital of Saudi Arabia. It is a very big city. Many people from different nationalities come and work in it. They work in different sectors.

Masumi: What is your job? Are you an engineer?

Ali: No ,I am not. I am a journalist. I work at Tabuk Magazine. I love my job very much. What about you?

Masumi: I work in a bank. It is in the center of Tokyo. I have been working there since 2010.

Ali: What do you eat for breakfast?

Masumi: We have rice, fish, and soup. And you?

Ali: We eat cheese, yoghurt and bread. What do you have in the evening?

Masumi: We have some fish with beans.

Ali: What do you like doing at the weekend? We go for walks and have dinner.

Masumi: What do you do at your vacations?

Ali :We go to the sea for swimming and diving.

Masumi: Nice to meet you Ali. And you

Part 2

Ahmad: Good afternoon?

Richard: Good afternoon. How are you?

Ahmad: I am fine thank you. How about you?

Richard: I am fine thanks.

Ahmad: What is your name?

Richard: My name is Richard.

Ahmad: Where do you live? 
Richard: I live in Brooklyn, New York. And you?

Ahmad: I live in, Manama, Bahrain.

Richard: What do you have for breakfast?

Ali: I have bread, honey and cheese. And you?

Richard: I have toast and cereal for breakfast.

Ali: What do you have for dinner?

Richard: For dinner, I usually eat chicken, fish, or sea food. What do you do?

Ali: I am a nurse at Manama public hospital. What do you do?

Richard: I am a waiter.

Ali: How do you go to work?

Richard: I ride my bike to work.

Ali: What do you do at home in your extra time?

Richard: At home I like cooking for my friends.

Ali: What do you eat when you do not have time? I eat snack.

Richard: Nice to meet you.

Ali: Thanks a lot. Good luck Richard.

\section{Part 3}

Simon: Good morning. What is your name?

Fahad: Good morning. My name is Fahad. Nice to meet you.

Simon: And you. Where are you from?

Fahad: I am from Riyadh, Saudi Arabia. Where are you from?

Simon: I am from England. How old are you?

Fahad: I am 32 years old. And you?

Simon: I am 30 years old. Where do you live?

Fahad: I live in Riyadh. Do live in London?

Simon: Yes, I do. What do you have for breakfast?

Fahad: I have bread with cheese, eggs, yoghurt and tea. What about you?

Simon: I have cheese, milk and honey. What is your big meal of the day?

Fahad: It is the evening meal.

Simon: How many meals do you have for Ramadan?

Fahad: In Ramadan, we have two meals. One before dawn, and one after the sunset.

Simon: Nice to meet you.

Fahad: And you.

Passage (1)The Dialogue The Secret Millionaire

Rashid: Good afternoon. My name Is Rashid. I am a journalist. I would like to know more about the secret millionaire for this week. May I ask you some questions?

James: You are welcome.

Rashid: What is the Secret Millionaire of this week?

James: It is a programme on UK TV's Channel 4.

Rashid: Who is the Secret Millionaire today?

James: He is Colin Cameron.

Rashid: When did he start business?

James: He started business when he was 25 years old.

Rashid: With whom does she live?

James: He lives with his wife and his two teenage sons.

Rashid: How much is his work worth now?

James: It is worth now \$ 60 million.

Rashid: What does he drive?

James: He drives a yellow Lamborghini and he has a private plane.

Rashid: When did he leave your family?

James: He left his family last weekend.

Rashid: Where is he staying now?

James: He is staying with a married couple Roger and Margaret. 
Rashid: Where do Roger and Margaret live?

James: They live in a small flat on the $8^{\text {th }}$ floor of an apartment block.

Rashid: What do they run?

James: They run a hostel for homeless teenage boys.

Rashid: What is Colin missing while staying with Roger and Margaret?

James: He is missing his family.

Rashid: Thank you so much for this interview.

James: You are welcome Rashid.

Passage (2) The dialogue Past, Present, and Future

Part 1

Fatima: Good morning

Milena: Good morning. What is your name?

Fatima: My name is Fatima. And you?

Milena: I am Milena.

Fatima: Where are you from?

Milena: I am from Czech. I was born in Prague. Where are you from Fatima?

Fatima: I am Omani. I was born in Muscat. What are you studying?

Milena: I am studying English, Psychology, and Economics.

Fatima: What is your father's job?

Milena: He is a journalist.

Fatima: What does your mother do?

Milena: She is a chef in a restaurant in the Old Town.

Fatima: What are you excited about?

Milena: I am excited about going to London.

Fatima: Why are you a little bit worried?

Milena: Because I am thinking about my family.

\section{Part 2}

Khaled: Hello. My name is Khaled.

George: Hello. I am Georg. Nice to meet you.

Khaled: And you. What is your job?

George: I am an architect. What do you do?

Khaled: I am a teacher of English language. Where are you from?

George: I am from Germany. And you?

Khaled: I am Jordanian. Where did you grow up?

George: I grew up in Frankfurt. And you?

Khaled: I grew up in Tabuk. When are you moving to America? Why?

George: I am moving to America next year to teach at the University of California for three years.

Khaled: Where are you going to live?

George: I am going to live in the University campus.

Khaled: Good luck. Nice to meet you.

George: And you.

\section{Part 3}

Saeed: Hello. I'm Saeed. What is your name?

Archie: My name's is Archie.

Saeed: Hello, Archie. Where are you from?

Archie: I am from Scotland. And you?

Saeed : I am from Egypt. Where were you born?

Archie: I was born in Glasgow.

Saeed: What did you study?

Archie: I studied Biology, chemistry, and physics . What did you study?

Saeed: I studied engineering at Cairo University. What is your dream?

Archie: I want to work with my wife Fiona in developing countries as Zamibia in Southern Africa. Where do you work now?

Saeed: I work at the national center for researches. How do you feel about your next trip?

Archie: I am very excited but a bit nervous. Nice to meet you Saeed.

Saeed: Good luck Archie. 